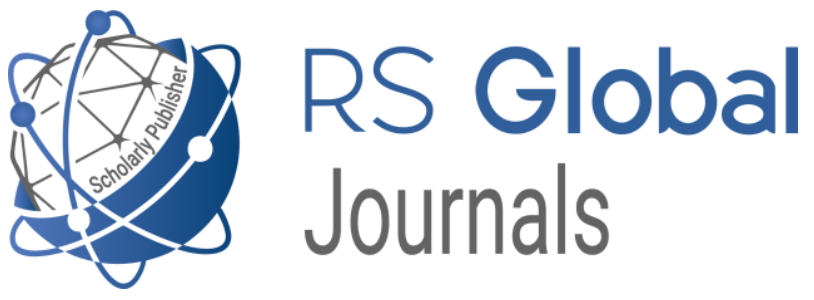

Scholarly Publisher

RS Global Sp. z O.O.

ISNI: 0000000484952390

Dolna 17, Warsaw, Poland 00-773

Tel: +48226022703

Email: editorial_office@rsglobal.pl

JOURNAL International Journal of Innovative Technologies in Social Science

p-ISSN 2544-9338

e-ISSN 2544-9435

PUBLISHER RS Global Sp. z O.O., Poland

ARTICLE TITLE SHEVARDNADZE'S DIPLOMATIC CAROM OF 1983 YEAR

AUTHOR(S) Kuprashvili Henri.

Kuprashvili Henri. (2021) Shevardnadze's Diplomatic Carom of 1983 Year. International Journal of Innovative Technologies in Social Science. 3(31). doi:

10.31435/rsglobal_ijitss/30092021/7671

DOI

https://doi.org/10.31435/rsglobal_ijitss/30092021/7671

RECEIVED

19 July 2021

ACCEPTED

31 August 2021

PUBLISHED

04 September 2021

LICENSE

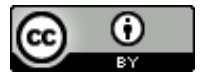

This work is licensed under a Creative Commons Attribution

4.0 International License.

(C) The author(s) 2021. This publication is an open access article. 


\title{
SHEVARDNADZE'S DIPLOMATIC CAROM OF 1983 YEAR
}

\author{
Kuprashvili Henri, Doctor of Political Sciences, Professor, Faculty of Law and International \\ Relations, Georgian Technical University, Georgia, \\ ORCID ID: https://orcid.org/0000-0002-7013-1407
}

DOI: https://doi.org/10.31435/rsglobal_ijitss/30092021/7671

\section{ARTICLE INFO}

Received 19 July 2021

Accepted 31 August 2021

Published 04 September 2021

\section{KEYWORDS}

Diplomacy, Georgia, Eduard Shevardnadze, Politics, Russian-Georgian Agreement, Russia.

\begin{abstract}
Even in the conditions of the Soviet Empire, the conquered Georgia did not forget its condition and consequently, unilaterally violated "Treaty of Georgievsk" by Russia. Georgia did not miss the opportunity, took advantage of the moment and used the Kremlin's instructions to protect the country's interests, showed the world political community that Georgia should not be considered a politically written-off country. Eduard Shevardnadze took political points from the conqueror Russia, as well created the illusion of effectively carrying out the Kremlin's task, and at the same time avoided the solemn celebration of the annexation. That is, he literally caught two rabbits fulfilled the task of the Kremlin and paid tribute to the Georgian cause.
\end{abstract}

Citation: Kuprashvili Henri. (2021) Shevardnadze's Diplomatic Carom of 1983 Year. International Journal of Innovative Technologies in Social Science. 3(31). doi: 10.31435/rsglobal_ijitss/30092021/7671

Copyright: (C) 2021 Kuprashvili Henri. This is an open-access article distributed under the terms of the Creative Commons Attribution License (CC BY). The use, distribution or reproduction in other forums is permitted, provided the original author(s) or licensor are credited and that the original publication in this journal is cited, in accordance with accepted academic practice. No use, distribution or reproduction is permitted which does not comply with these terms.

Introduction. By the instruction of the Kremlin, since the 60s of the XX century in the Soviet Union began another ideologically and politically targeted campaign-farce: all Soviet Republics (socalled autonomous formations of all levels) should be celebrated Autochthonous of the Republic - the anniversary of the "voluntary unification" of the people with Russia. Moscow tried to establish the common sense that Russia was not an conqueror, but it only performed the request of these peoples on joining with Russia and thus they became in the part of the Russian Empire.

Diplomatic carom. In order to execute the directive, the people, part of the Soviet Empire of Russia soon began celebrating the anniversary dates of the "voluntary unification" of their territories with Russia. Who dared to resist the Kremlin's directive? Accordingly, the party leaders of the republics adjusted the dates to the ideological spirit of the directive and started celebrations in Ukraine, Yakutia, Armenia...

According to the directive issued by Moscow preparations for a similar event have started in Georgia too. But the beginning or the announcement of a specific anniversary date caused some confusion in the Georgian society at that time. This was caused by the fact that the First Secretary of the Central Committee of the Communist Party of Georgia, at that time, Eduard Shevardnadze (1928-2014) in a special report dedicated to this event in 1976 said that Georgia should celebrate the 200th anniversary of "Georgia's unification with Russia" in 1983 and is necessary to start preparing for it today.

Confusion, astonishment and indignation were caused by the mention of the term "unification" in the context of 1783 , because since until now it was a well-known for everybody and scientifically established fact that Russia annexed Kartli-Kakheti in 1801 and not in 1783 and the "anniversary" date should have been in 2001 but not in 1983. Many considered that, at first glance, the admission of such "inaccuracy" by E. Shevardnadze was another manifestation of his flattery towards the Kremlin. To show himself, he must complete the Kremlin's task as soon as possible, during his reign. The effect would be exactly that. Although for prove himself there was not even close to 1976 the anniversary date; the latest "anniversary" date of the "unification" should have been only in 2001, before that, no one knew what would happen in 25 years. Therefore, the anniversary date was artificially postponed 
for 1983 year; the term "unification" was willfully used in an inappropriate context to denote a completely different event, when it was approaching not "unification" but anniversary of the friendship agreement so-called "Treaty of Georgievsk"1 between the Kingdom of Kartli-Kakheti and the Russian Empire. This document, an agreement, so-called "Treaty of Georgievsk" signed between the Kingdom of Kartli-Kakheti and the Russian Empire in 1783 is thoroughly analyzed by Luis le Fur (1870-1943), the Professor of International Law at the University of Paris (Sorbonne), in the work "Georgia and International Law", 2 published in French in Paris, in 1932.

For the leaders of the USSR Communist Party, committing such blasphemy (voluntary manipulation with historical dates) was not a problem, they could do it freely, including the leaders of the Republican level, so unlimited was their power. For many, it seemed very unbelievable that a statesman of such a level (even a historian by profession) as Shevardnadze was, such a blunder was made, and "rolled" for the Kremlin, that to falsify the historical dates publicly that are established by the historians as "one hundred percent" and are very painful for Georgians.

The fact is that there was a fuss in the press at that time because of the mentioned formulate. Close historians have seriously begun to search for "arguments" to justify this apparent inaccuracy in order to save the Georgian leader from apparent confusion.

At that time, in an atmosphere of lack of information and charged with emotions, it was difficult for an unsuspecting person to understand what was happening in terms of an objectively political understanding of the event. Therefore, it was not surprising that there was an emotional turmoil then (obviously, on an unofficial level, within the framework of the Soviet country). But if we carefully analyze what happened, observe the ongoing processes from another angle, we cannot miss a particularly important moment in this "celebration".

When evaluating this phenomenon, one circumstance turns attention. When analyzing the information spread in the Georgian central press about this celebration in 1976-1983, one important regularity is observed: the term "Georgia's unification with Russia", which was officially proposed by Shevardnadze in 1976 (which immediately caused a great stir), after some time, both in official documents and in the mass media, it is gradually, imperceptibly undergoing a transformation, gradually falling out of use and finally, by 1983, acquires the meaning that the Republic should celebrate not the "unification of Georgia with Russia", but the date of a completely different event, thus, Georgians should celebrate the 200th anniversary from the signing of Russian-Georgian Agreement, the so-called "Treaty of Georgievsk". So, actually, contrary to the Kremlin's directive, Georgia was celebrating not the anniversary of Georgia's "voluntary" unification with Russia, Georgia's annexation by Russia, the loss of statehood of Georgians, but was celebrating the anniversary date of the signing of an agreement between two independent states the Kingdom of Kartli-Kakheti and the Russian Empire.

Diplomacy has its own complex, specific language; it is distinguished by the peculiarities of expression the idea (by the way, it is a well-known fact that $E$. Shevardnadze later became the first diplomat of the huge Russian Empire when he was the Minister of Foreign Affairs of the Soviet Union in 1985-1990). In short, Georgia responded to the Kremlin directive in diplomatic language. In the uncontrolled dictatorship of the communist Kremlin and the atmosphere of the political pressure, he was still able to respond to the invader with a deeply thought-out, encrypted political move. In ordinary language, this meant that Georgia, due to the falsity of fate, placed in another state, included in Russian Soviet Empire, loose its independence, tried to remind the political elite of the civilized world of the existence of an agreement between two independent states and the unforgettable aspiration of the Georgian people to restore independence. Therefore, even in the conditions of the Soviet Empire, the conquered Georgia did not forget its condition and consequently, unilaterally violated "Treaty of Georgievsk" by Russia. At the point there was an opportunity to raise forward anything, that document was raised forward. It is clear that at the time even the mention was incredible the violation by Russia the agreement reached between the Russian-Georgian Democratic Republic on May 7, 1920, ${ }^{3}$ The fact is that Georgia did not miss the opportunity, took advantage of the moment and used the Kremlin's

\footnotetext{
${ }^{1}$ Treaty of Georgievsk, 1783. Treaty established between Her Imperial Majesty and Tsar Irakli II of Karli and Kakhetia. Translated from the Russian by Russell E. Martin. http://www4.westminster.edu/staff/martinre/Treaty.html

2 Louis Le Fur. La Géorgie et le Droit des Gens. Paris, 1932. https://premiererepubliquedegeorgie.wordpress.com/2013/10/04/la-georgie-et-le-droit-des-gens-par-louis-le-fur-paris-1932/ ${ }^{3}$ Peace Treaty, concluded in Moscow on 7 May 1920, between the Russian Socialist Federal Soviet Republic (RSFSR) and the Democratic Republic of Georgia. May 7, $1920 \mathrm{http} / / /$ soviethistory.msu.edu/19212/transcaucasia/transcaucasia-texts/georgian-independence/
} 
instructions to protect the country's interests, showed the world political community that Georgia should not be considered a politically written-off country.

Conclusions. It is difficult to say, whether E. Shevardnadze had intended such a result from the very beginning. We should think that his 1976 report was more focused on implementing the Kremlin directive. Only then occurs the "headache", looking for ways to get out of this utterly disgusting "celebrations" and come out with dignity. Anyway, one thing is for sure, Eduard Shevardnadze took political points from the conqueror Russia, as well created the illusion of effectively carrying out the Kremlin's task, and at the same time avoided the solemn celebration of the annexation. That is, he literally caught two rabbits - fulfilled the task of the Kremlin and paid tribute to the Georgian cause.

\section{REFERENCES}

1. Treaty of Georgievsk, 1783. Treaty established between Her Imperial Majesty and Tsar Irakli II of Karli and Kakhetia. Translated from the Russian by Russell E. Martin. Retrieved from http://www4.westminster.edu/staff/martinre/Treaty.html

2. Fur, Louis Le. 1932. La Géorgie et le Droit des Gens. Paris: Publisher A. Pedone. Retrieved from https://premiererepubliquedegeorgie.wordpress.com/2013/10/04/la-georgie-et-le-droit-des-gens-par-louisle-fur-paris-1932/

3. Peace Treaty, concluded in Moscow on 7 May 1920, between the Russian Socialist Federal Soviet Republic (RSFSR) and the Democratic Republic of Georgia. May 7, 1920. Retrieved from http://soviethistory.msu.edu/1921-2/transcaucasia/transcaucasia-texts/georgian-independence/ 